\title{
Estimation of genetic parameters and relationships between type traits and milk yield of Holstein cows in Turkey
}

[Estimativa de parâmetros genéticos e relações entre características de tipo e produção de leite das vacas Holstein na Turquia]

$$
\text { O. } \operatorname{Ermetin}^{1} \text { (D) , B. Dağ } \breve{g}^{(1 D}
$$

${ }^{1}$ Yozgat Bozok University, Faculty of Agriculture, Department of Animal Science, Yozgat, Turkey ${ }^{2}$ Selcuk University, Faculty of Agriculture, Department of Animal Science, Turkey

\begin{abstract}
In this study, milk yield, reproductive yield, and type traits of 533 Holstein cows in the first lactation raised in 54 farms were examined. In the three-year study, phenotypic (rP) and genetic (rG) correlations between type traits and milk yield were estimated based on the variance elements and heritability of the type traits of Holstein cows in the first lactation. Linear identification and scoring systems have been applied to classify the cows according to type traits. Heritability and correlations were estimated with ASREML models. The type traits included stature, angularity, rump width, hocks, rear udder height, central ligament, teat length, body capacity, feet and legs, udder composite and final score for genetic correlations with 305-day milk yield were estimated as $-0.49,-0.14,-0.93,0.35,0.40,0.11,-0.65,0.70,0.31,0.54$, and 0.70 , for phenotypic correlations were estimated as $0.28,0.28,0.30,0.21,0.35,0.39,-0.06,0.46,0.48,0.56$, and 0.58 respectively. Among the phenotypic correlations between the type traits, especially the phenotypic correlations between the final score and various type traits were found to be high and significant. The fact that these traits are in high correlation with other traits and milk yield may enable these to be used as indirect selection criteria in the selection for milk yield.
\end{abstract}

Keywords: classification, genetic correlation, heritability, Holstein, type traits

\section{RESUMO}

Neste estudo, foram examinadas a produção de leite, a produção reprodutiva e as características de tipo de 533 vacas Holstein na primeira lactação criadas em 54 fazendas. No estudo trienal, as correlações fenotípicas (rP) e genéticas $(r G)$ entre características de tipo e produção de leite foram estimadas com base nos elementos de variação e hereditariedade das características de tipo das vacas Holstein na primeira lactação. Sistemas de identificação linear e de pontuação foram aplicados para classificar as vacas de acordo com os traços de tipo. A hereditariedade e correlações foram estimadas com os modelos ASREML. Os traços de tipo incluíam estatura, angularidade, largura da alcatra, jarretes, altura do úbere traseiro, ligamento central, comprimento das tetas, capacidade corporal, pés e patas, composição do úbere e pontuação final para correlações genéticas com a produção de leite de 305 dias foram estimados como -0. 49, -0,14, -0,93, 0,35, 0,40, 0,11, -0,65, 0,70, 0,31, 0,54, e 0,70, para correlações fenotípicas foram estimadas como 0,28,0,28,0,30,0,21,0,35, 0,39, -0,06, 0,46, 0,48, 0,56, e 0,58 respectivamente. Dentre as correlações fenotípicas entre os traços de tipo, especialmente as correlações fenotípicas entre a pontuação final e vários traços de tipo foram encontradas como altas e significativas. $O$ fato destes traços estarem em alta correlação com outros traços e a produção de leite pode permitir que sejam usados como critérios de seleção indiretos na seleção para a produção de leite.

Palavras-chave: classificação, correlação genética, herdabilidade, Holstein, características de tipo

\section{INTRODUCTION}

The goal of breeding in dairy cattle is to increase the lifetime yield per animal and unit time. One of the important factors affecting profitability in dairy cattle breeding is cows that have high yields and maintain this yield for many years. To increase profitability in dairy cattle breeding, cows must have a suitable body structure, ensure

Corresponding author: orhan.ermetin@yobu.edu.tr Submitted: June 8, 2021. Accepted July 16, 2021. 
regular reproduction, and high milk yield. The ability of cows to bear the burden of high yield for many years is only possible if their bodies are in a suitable structure. The selection of highly productive animals that can yield for many years can be predicted by indexes taken from early age measurements (Tapk1 and Guzey, 2013). It is desirable that the body structures of cows with high milk yield show dairy characteristics, that their rear and fore legs are smooth and firm, and that the udder is in a suitable structure that is firmly attached to the body (Smothers et al., 1993). Choosing cattle with better type traits as a breeder will also increase the animal's endurance for milk production (Wasana et al., 2015).

In keeping a cow in the herd, it is important to have a body condition that can withstand milk yield, reproductive yield, and longevity, that is, high milk yield. Moderate and positive correlations between breeding time and milk yield within the herd were reported, ranging from 0.31 to 0.48 (Irano et al., 2014; Wasana et al., 2015). For dairy cattle to last longer and give more yield, it is necessary to choose according to their type traits when estimating breeding values. Especially udder and foot and leg traits affect the longevity of dairy cows. These traits have a moderate degree of heritability in cows in first lactation (Kern et al., 2015). Valloto (2016) noted that there is a positive genetic correlation between milk yield and udder structure, and high-milk-yielding animals can be successfully identified by scoring according to udder traits in first lactation. It is reported that it is possible to obtain more durable and long-living animals with higher milk, meat, and reproductive yields by taking advantage of their type traits, and this has a positive effect on profitability (Stefani et al., 2018). Type traits have been used as a tool for indirect selection to improve reproductive efficiency (Almeida et al., 2017). In indirect selection indexes, the share of type traits can range from $10 \%$ to $50 \%$ (Özcan, 2001; Yaylak, 2008).

To determine the suitability of an animal for breeding, the need to consider its measurable traits, such as milk, meat, and reproductive yields, as well as its economically important and visually identifiable characteristics, has been accepted in all breeding programs. In addition to milk yields, type traits should be considered in breeding evaluations of cows (Yaylak, 2008). As a result of addressing these traits together, it may be possible to culling cows who will not provide genetic and economic benefits in the future in the herd belonging to the farm at an early stage and increase the number of cows with high milk yield, udder attachments and strong udders in the future (Çerçi, 2006). Inbreeding studies to increase milk yield, it is of great importance to focus on various body traits and udder sizes associated with milk yield (Kul and Erdem, 2008). It is possible to obtain long-living animals with high milk, meat, and reproductive yields and to make production profitable while increasing milk yield by taking advantage of the type traits associated with milk yield (Kumlu, 2000; Fatehi et al., 2003; Çerçi, 2006; Erkmen, 2020). Conducting an assessment based on type traits can also help illuminate the reasons for removal from the herd in a cattle population. In this way, it may also be possible to take the necessary measures to reduce the rates of removal from the herd. Also, knowing the herd life of cows is important for planning herd management, feeding, and breeding methods.

\section{MATERIALS AND METHODS}

As the material of the study, data obtained from Holstein cattle raised in 76 farms within the borders of Konya province, where pedigrees were held were used. However, during the data evaluation studies, the values of 46 heads of cattle in 22 farms, which were found to be incomplete or inaccurate, were excluded from the evaluation, and the study was completed with 3-year data of 533 heads of cattle in 54 farms.

Linear identification and scoring systems specified by Holstein (1997) and Özcan (2001), were applied to make classification according to type traits. 579 heads of cattle in 76 farms were scored and processed on classification cards between 30 and 150 days of the first lactation.

Of the 17 traits discussed in the linear definition, only the stature was determined in $\mathrm{cm}$, and the measuring cane was used for this. In terms of the other 16 traits, cows were given scores ranging from 1-9 to 57-90 for the final score. Descriptive statistics for properties are summarized in Table 1. 
Table 1. Descriptive statistics of data set for linear type traits and non-linear traits

\begin{tabular}{|c|c|c|c|c|c|c|}
\hline \multirow{2}{*}{ Type traits } & & \multicolumn{2}{|c|}{ Score } & \multirow{2}{*}{$\begin{array}{l}\text { Ideal } \\
\text { Score } \\
\end{array}$} & \multirow[t]{2}{*}{ Mean } & \multirow[t]{2}{*}{ SD } \\
\hline & & 1 & 9 & & & \\
\hline Stature & STA & $130 \mathrm{~cm}$ & $154 \mathrm{~cm}$ & 145 & 140.73 & 5.06 \\
\hline Angularity & ANG & Too coarse, broad & $\begin{array}{l}\text { Too shallow, } \\
\text { sharp }\end{array}$ & $7-9$ & 6.99 & 0.89 \\
\hline Body Depth & $\mathrm{BD}$ & Too narrow & Too wide & 7 & 6.79 & 0.80 \\
\hline Chest Width & $\mathrm{CW}$ & Too narrow & Too wide & 9 & 6.56 & 1.20 \\
\hline Rump Width & RW & Too narrow & Too wide & $7-9$ & 6.44 & 1.12 \\
\hline Rump Angle & RA & Ascending & Descending & 5 & 5.50 & 0.99 \\
\hline Rear Legs Set & RLS & Too steep & Too shallow & 5 & 5.52 & 0.98 \\
\hline Foot Angle & FA & Too low & Too high & 9 & 6.42 & 1.16 \\
\hline Hocks & HQ & Too coarse & Too dry & 9 & 6.26 & 1.17 \\
\hline Rear Legs Rear View & RLRV & Knees too close & Parallel & $5-9$ & 6.08 & 1.29 \\
\hline Fore Udder Attachment & FUA & Too weak & Too strong & $7-9$ & 6.67 & 1.17 \\
\hline Rear Udder Height & RUH & Too low & Too high & 9 & 6.68 & 1.12 \\
\hline Central Ligament & CL & Too weak & Too strong & 9 & 6.53 & 1.30 \\
\hline Udder Depth & UD & Too low & Too high & 5 & 5.24 & 0.96 \\
\hline Front Teat Placement & FTP & Out of the lobe & Into the lobe & 6 & 5.05 & 0.95 \\
\hline Teat Length & $\mathrm{TL}$ & Too short & Too long & 5 & 4.94 & 0.81 \\
\hline Rear Teat Placement & RTP & Too wide & Too close & 5 & 4.97 & 0.79 \\
\hline Dairy Form & DF & 57 & 90 & $>80$ & 79.07 & 4.86 \\
\hline Body Capacity & $\mathrm{BC}$ & 57 & 90 & $>80$ & 77.80 & 4.85 \\
\hline Feet and Legs & $\mathrm{F} \& \mathrm{~L}$ & 57 & 90 & $>80$ & 77.31 & 4.74 \\
\hline Udder Composite & UC & 57 & 90 & $>80$ & 77.82 & 5.25 \\
\hline Final Score & FS & 57 & 90 & $>80$ & 78.12 & 4.52 \\
\hline
\end{tabular}

Computer programs MS Excel and JMP (Statistics..., 1995) have been used to prepare the studied traits for analysis, and Minitab (Version for Windows. Minitab Release 12.1. 1998) has been used to calculate descriptive statistics.

The animal model used for the analysis of type traits is given below with the matrix software,

$\mathrm{y}=\mathrm{Xb}+\mathrm{Za}+\mathrm{e}$

here, $y$ : observation values of the vector, $b$ : fixed effects vector (farm factor 54-level), a: chancedependent genetic effects vector (breeding values vector), $\mathrm{X}$ and $\mathrm{Z}$ : pattern matrices of fixed and chance-dependent factors, and e: chancedependent error effects vector. Expected values of the model are expressed by the following equation:

$$
E\left(\begin{array}{l}
\mathbf{y} \mid \mathbf{b}, \mathbf{a}, \sigma_{e}^{2} \\
\mathbf{a} \mid \mathbf{A}, \sigma_{\mathbf{a}}^{2} \\
\mathbf{e}
\end{array}\right)=\left(\begin{array}{c}
\mathbf{X b}+\mathbf{Z a} \\
\mathbf{0} \\
\mathbf{0}
\end{array}\right)
$$

the variance-covariance matrix can also be expressed by the following equation:

$$
\operatorname{Var}\left(\begin{array}{l}
\mathbf{y} \\
\mathbf{a} \\
\mathbf{e}
\end{array}\right)=\left(\begin{array}{ccc}
\mathbf{Z A} \sigma_{\mathrm{a}}^{2} \mathbf{Z}^{\prime}+\mathbf{I}_{\mathrm{n}} \sigma_{e}^{2} & \mathbf{Z A} \sigma_{\mathrm{a}}^{2} & \mathbf{I}_{\mathrm{n}} \sigma_{e}^{2} \\
\mathbf{A} \sigma_{\mathrm{a}}^{2} \mathbf{Z}^{\prime} & \mathbf{A} \sigma_{\mathbf{a}}^{2} & \mathbf{0} \\
\mathbf{I}_{\mathrm{n}} \sigma_{e}^{2} & \mathbf{0} & \mathbf{I}_{\mathrm{n}} \sigma_{e}^{2}
\end{array}\right)
$$

This expression $\sigma_{\mathrm{a}}^{2}$ refers to the additive genetic variance, A to the affinity matrix, and $\sigma_{e}^{2}$ the error variance. Accordingly, the degree of heritability of type traits has been calculated by the following equation:

$$
h^{2}=\frac{\sigma_{\mathrm{a}}^{2}}{\sigma_{\mathrm{a}}^{2}+\sigma_{e}^{2}}
$$

ASREML (Gilmour et al., 2007) computer package program was used to estimate additive genetic variance, error variance, and hereditability of type traits. 


\section{RESULTS AND DISCUSSION}

The phenotypic $\left(\sigma^{2} \mathrm{p}\right)$, genetic $\left(\sigma^{2} \mathrm{a}\right)$, and residual $\left(\sigma^{2} e\right)$ variances and heritability $\left(h^{2}\right)$ of type traits are given in Table 2 . The heritability of type traits ranged from 0.01 to 0.34 .

In this study, the heritability of stature was estimated as $0.16 \pm 0.167$. Royal et al. (2002), reported the lowest heritability for stature as 0.16 , and Pryce et al. (2000) reported the highest heritability as 0.59 . In studies conducted on
Holstein cows in Turkey, the heritability of stature was determined between 0.25 and 0.53 (Özet, 2001; Duru, 2005; Çerçi, 2006; Erkmen, 2020).

The estimated heritability for angularity is $0.21 \pm 0.141$. As a result of the research, the heritability level determined for angularity was higher than some research results on the subject (Duru, 2005; Çerçi, 2006), while it was lower than the research results conducted by Özet (2001) and Erkmen (2020).

Table 2. Phenotypic $\left(\sigma_{p}^{2}\right)$, genetic $\left(\sigma_{a}^{2}\right)$ and residual $\left(\sigma_{e}^{2}\right)$ variances and heritability $\left(\mathrm{h}^{2}\right)$ for milk production traits

\begin{tabular}{lcccc}
\hline & $\sigma_{p}^{2} \pm \mathrm{SE}$ & $\sigma^{2}{ }_{a} \pm \mathrm{SE}$ & $\sigma^{2} \pm \mathrm{SE}$ & $\mathrm{h}^{2} \pm \mathrm{SE}$ \\
\hline STA & $14.411 \pm 0.958$ & $2.264 \pm 2.435$ & $12.147 \pm 2.372$ & $0.16 \pm 0.167$ \\
ANG & $0.469 \pm 0.031$ & $0.098 \pm 0.068$ & $0.371 \pm 0.065$ & $0.21 \pm 0.141$ \\
BD & $0.427 \pm 0.028$ & $0.039 \pm 0.053$ & $0.388 \pm 0.055$ & $0.09 \pm 0.123$ \\
CW & $0.898 \pm 0.058$ & $*$ & $0.898 \pm 0.058$ & $*$ \\
RW & $0.714 \pm 0.047$ & $0.122 \pm 0.096$ & $0.592 \pm 0.096$ & $0.17 \pm 0.132$ \\
RA & $0.696 \pm 0.045$ & $*$ & $0.696 \pm 0.045$ & $*$ \\
RLS & $0.775 \pm 0.050$ & $0.005 \pm 0.099$ & $0.770 \pm 0.101$ & $0.01 \pm 0.119$ \\
FA & $0.784 \pm 0.051$ & $*$ & $0.784 \pm 0.051$ & $*$ \\
HQ & 0.8440 .055 & $0.023 \pm 0.095$ & $0.821 \pm 0.105$ & $0.03 \pm 0.113$ \\
RLRV & $1.008 \pm 0.066$ & $0.101 \pm 0.133$ & 0.9080 .135 & $0.10 \pm 0.130$ \\
FUA & $0.806 \pm 0.525$ & $0.019 \pm 0.084$ & $0.787 \pm 0.094$ & $0.02 \pm 0.103$ \\
RUH & $0.911 \pm 0.061$ & $0.243 \pm 0.155$ & $0.668 \pm 0.144$ & $0.27 \pm 0.164$ \\
CL & $1.119 \pm 0.077$ & $0.377 \pm 0.222$ & $0.742 \pm 0.202$ & $0.34 \pm 0.190$ \\
UD & $0.715 \pm 0.046$ & $*$ & $0.715 \pm 0.046$ & $*$ \\
FTP & $0.537 \pm 0.035$ & $*$ & $0.537 \pm 0.035$ & $*$ \\
TL & $0.467 \pm 0.031$ & $0.130 \pm 0.084$ & 0.3370 .078 & $0.28 \pm 0.174$ \\
RTP & $0.397 \pm 0.026$ & $*$ & $0.397 \pm 0.026$ & $*$ \\
\hline DF & $13.489 \pm 0.886$ & $1.492 \pm 1.819$ & $11.998 \pm 1.854$ & $0.11 \pm 0.114$ \\
BC & $14.519 \pm 0.994$ & $4.971 \pm 2.841$ & $9.548 \pm 2.573$ & $0.34 \pm 0.172$ \\
F\&L & $14.398 \pm 0.977$ & $4.632 \pm 2.588$ & $9.766 \pm 2.370$ & $0.32 \pm 0.132$ \\
UC & $15.237 \pm 1.042$ & $5.114 \pm 2.956$ & $10.124 \pm 2.685$ & $0.34 \pm 0.122$ \\
FS & $11.193 \pm 0.756$ & $3.304 \pm 1.944$ & $7.888 \pm 1.809$ & $0.30 \pm 0.167$ \\
\hline F & & & \\
\hline
\end{tabular}

*: It couldn't be calculated, SE: Standart Error

STA: Stature, ANG: Angularity, BD: Body Depth, CW: Chest Width, RW: Rump Width, RA: Rump Angle, RLS: Rear Legs Set, FA: Foot Angle, HQ: Hocks, RLRV: Rear Legs Rear View, FUA: Fore Udder Attachment, RUH: Rear Udder Height, CL: Central Ligament, UD: Udder Depth, FTP: Front Teat Placement, TL: Teat Length, RTP: Rear Teat Placement, DF: Dairy Form, BC: Body Capacity, F\&L: Feet and Legs, UC: Udder Composite, FS: Final Score.

Heritability was estimated to be quite low $(0.09 \pm 0.123)$ for body depth. The value determined for body depth is lower than many research results on the subject (Özet, 2001; Royal et al., 2002; Duru, 2005; Erkmen, 2020). While the degree of heritability determined as $0.17 \pm 0.132$ for the rump width is consistent with some research results (Royal et al., 2002; Duru, 2005) it was found to be low for most research results (Pryce $e t$ al., 2000; Özet, 2001; Erkmen, 2020).
The estimated heritability for the rear legs rear view set was found to be very low $(0.01 \pm 0.119)$. Similar results were determined by Fatehi et al. (2003), and a low-to-moderate heritability was estimated between 0.12 and 0.27 in general studies (Duru, 2005; Çerçi, 2006; Erkmen, 2020). In this study, the estimated heritability for hocks was determined as $0.03 \pm 0.113$, and in the studies conducted (Duru, 2005; Çerçi, 2006; Erkmen, 
2020), a low level of heritability was determined ranging from 0.07 to 0.14 . Although the degree of heritability $(0.10 \pm 0.130)$ determined for the rear legs set is consistent with the results of the literature (Fatehi et al., 2003; Duru, 2005; Erkmen, 2020) moderate heritability was estimated between 0.20 and 0.26 in many other studies (Pryce et al., 2000; Toosi and Efterhari, 2000; Kadarmideen and Wegman, 2003).

The additive genetic variance and therefore heritability for udder depth, front teat placement, and rear teat placement among udder traits were estimated to be zero, but the fact that the additive genetic variance was zero caused the heritability to be estimated to be zero.

The heritability of the fore udder attachment was determined as $0.02 \pm 0.103$, and similar results were determined by Duru (2005) and Özet (2001). But in most studies (Boldman et al., 1992; Pryce et al., 2000; Toosi and Efterhari, 2000; Kadarmideen and Wegman, 2003) moderate heritability was estimated that ranges from 0.21 to 0.29 .

The heritability $(0.27 \pm 0.164)$ determined for rear udder height was found to be higher than some study results (Özet, 2001; Duru, 2005). In many studies conducted on the subject, a moderate degree of heritability ranging from 0.20 to 0.31 was calculated, similar to the result of this study (Pryce et al., 2000; Toosi and Efterhari, 2000; Cassel, 2001; Kadarmideen and Wegman, 2003; Erkmen, 2020).

It was found that the heritability level of $0.34 \pm 0.190$ for the central ligament was similar to the results determined by Erkmen (2020). Again, in many studies conducted on the subject, heritability levels ranging from 0.17 to 0.026 were calculated (Cassel, 2001; Kadarmideen and Wegman, 2003; Duru, 2005). On the other hand, in a study conducted by Toosi and Efterhari, (2000), a fairly low level of heritability was determined at the level of 0.09 .

In the study, heritability for fore teat length was determined as $0.28 \pm 0.174$. In many studies conducted on the subject, moderate heritability was calculated for the fore teat length (Çerçi, 2006; Smothers et al., 1993; Toosi and Efterhari, 2000; Cassel, 2001). However, in a study conducted by Duru (2005), the heritability was determined as 0.45 . It has been reported that teat length has more economic value in terms of genetic significance than other type traits due to its moderate heritability, and therefore should be considered the most important type trait (Mikhchi et al., 2013).

The highest heritability was estimated at $0.21 \pm 0.141$ and $0.17 \pm 0.132$ for $\mathrm{ANG}$ and RW when type traits were considered. Considering udder traits, the highest heritability was found to be $0.34 \pm 0.190,0.28 \pm 0.174,0.27 \pm 0.164$ for $\mathrm{CL}$, TL, and RUH, respectively.

Among the traits for scoring, the heritability for the dairy form which was estimated as $0.11 \pm 0.134$ was found at a moderate level between 0.21 and 0.29 in other studies (Toosi and Efterhari, 2000; Dechow et al., 2003; Duru, 2005; Erkmen, 2020). The estimated heritability $(0.34 \pm 0.172)$ for body capacity was found to be consistent with some research results (Toosi and Efterhari, 2000; Cassel, 2001. However, a low heritability at a level of 0.10 and 0.16 was estimated in studies conducted by Erkmen (2020) and while a high (0.44) heritability was estimated in studies conducted by Kadarmideen and Wegman (2003).

Among the scoring traits, the heritability, determined as $0.32 \pm 0.172$ for feet and legs, was generally higher than the literature reports (Toosi and Efterhari, 2000; Dechow et al., 2003; Kadarmideen and Wegman, 2003; Duru, 2005). The heritability of the udder composite $(0.34 \pm 0.185)$ was again higher than the literature reports in which a low heritability has been determined (Toosi and Efterhari, 2000; Kadarmideen and Wegman, 2003; Duru, 2005; Çerçi, 2006). The heritability $(0.30 \pm 0.167)$ determined for the final score was higher than some research results (Smothers et al., 1993; Toosi and Efterhari, 2000) while many research results were found to be similar to the research result determined at a moderate level between 0.21 and 0.39 (Cassel, 2001; Dechow et al., 2003; Kadarmideen and Wegman, 2003; Çerçi, 2006; Erkmen, 2020). The heritability of UC and BC was found to be the highest with 0.34 . These values are also higher than those reported in the literature. For these two traits, it can be assumed that the genetic progression that will be achieved in selection in this population will be fast and high, if it depends on other factors. 
Phenotypic (rP) correlations between type traits are given in Table 3. Phenotypic correlations between type traits range from -0.071 (RLRW and UD) to 0.925 (FS and UC). It can be said that the correlation of traits with each other is usually high. As expected, the highest phenotypic correlations were usually estimated between scoring traits and linear identification traits associated with those traits. Because the evaluation of a scoring trait is made primarily by considering the linear traits associated with that particular trait. Among them, some of the linear identification traits also take precedence. For example, when giving udder scores, FUA, CL, UD, and RUH are more effective than other linear udder traits. In addition, high correlations were found between FS and UC (0.925), F\&L (0.868), BC (0.846) and DF (0.858); between UC and F\&L (0.752), BC (0.713) and DF (0.795); between F\&L and BC (0.744) and DF (0.740), between BC and DF (0.724). In the study, only negative but low correlations were found between UD and RLRV (-0.071) and between UD and CW (-0.013).

Çerçi (2006), estimated the phenotypic correlations between type traits were between 0.49 (RLS and RLRV) and 0.52 (CW and BD) in the first lactation and -0.51 (ANG and $\mathrm{CW}$ ) and 0.53 (FS and FUA, FS and FTP) in the second lactation. Pryce et al (2000) determined phenotypic correlations between 0.08 (FA and RLRV) and 0.88 (STA and BD) while Short and Lawlor (1992) determined between -0.21 (FA and RLRV) and 0.77 (CW and BD). In the study conducted by Mikhchi et al. (2013), they reported values ranging from -0.46 and -0.27 (RLS and F\&L) to 0.85 and 0.87 (UC and FS) for Jersey and Holstein cows. Rogers (1993), on the other hand, reported the phenotypic correlations between FA and UD and FA and FTP as zero.

The predicted phenotypic correlation (0.585) between DF and ANG in the study is higher than most of the other correlations. Kern et al. (2015), reported the phenotypic correlation between DF and ANG as 0.48 for Holstein.

Phenotypic correlations between BC and STA, $\mathrm{BD}, \mathrm{CW}, \mathrm{RW}$ and RA were estimated as 0.458 , $0.426,0.424,0.463$ and 0.079 , respectively. As mentioned before, while scoring traits are considered, the linear traits that make up that trait are used. Here, it is seen that while scoring for BC, STA and BD are primarily taken into consideration and the scores given are in the same direction. On the other hand, the relationship between the RLRV and UD and between the CW and UD was found to be inverse.

Phenotypic correlations between BC and STA are reported as 0.53 in Holstein and Jersey cows, and correlations between $\mathrm{BC}$ and $\mathrm{BD}$ as 0.75 in Holstein and 0.76 in Jersey cows (Visscher and Goddard 1995). These results reported for Holstein are higher than the values found for correlations between $\mathrm{BC}$ and STA and $\mathrm{BC}$ and $\mathrm{BD}$ in the present study.

Phenotypic correlations between F\&L and RLS, FA, HQ, and RLRV were found as 0.047, 0.338, 0.342 , and 0.204 , respectively. From here, it can be said that while scoring F\&L; the FA and RLS scores are primarily considered. Visscher and Goddard (1995) report that phenotypic correlations between F\&L and RLS are -0.27 and -0.46 for Holstein and Jersey cows. These results show that the value obtained for the same traits in the study is greater than the value reported for Holstein cows.

Phenotypic correlations between UC and FTP, RUH, CL, UD, FTP, TL and RTP were estimated as $0.517,0.472,0.529,0.158,0.349,0.224$ and 0.232 , respectively. Visscher and Goddard (1995), determined the phenotypic correlations between UC and FUA, RUH, CL, and FTP as $0.61,0.61,0.59$, and 0.52 for Holstein, respectively. Duru (2005) estimated the phenotypic correlations between UC and FUA, RUH, CL, ANG, FTP, TL, and RTP as 0.52, 0.36, $0.40,0.41,0.03,-0.13$, and 0.19 , respectively, and these values were lower than than the values obtained for the same traits in the study. The correlation that the researchers reported between UC and FUA, RUH, CL, and ANG in Holstein cows is similar to that obtained in this study, but the estimated value for UC and FTP is much lower than the researchers' reports.

Phenotypic correlations between final score and various type traits were found to be significant, high, and positive. The correlations calculated between FS and UC (0.925), F\&L (0.868), BC (0.846) and DF (0.858), between UC and F\&L (0.752), BC (0.713) and DF (0.795), between F\&L and BC (0.744), DF (0.740), between BC and DF (0.724), and between CL and RUH (0.733) were found to be high. These correlations 
were found to be quite high as an indication that the FS trait is calculated based on DF, BC, F\&L, and UC traits. Based on this result; when classifying cows according to their type traits, it has been observed that nonlinear traits used in calculating FS are more consistent with each other than linear traits. It was concluded that traits that show a low or negative correlation with each other among linear traits may not be required to be considered as classification criteria and the number of traits used can be reduced.

Table 3. Phenotypic (rP) correlations among type traits

\begin{tabular}{|c|c|c|c|c|c|c|c|c|c|c|c|c|}
\hline & ANG & $\mathrm{BD}$ & $\mathrm{CW}$ & RW & \multicolumn{2}{|c|}{ RA } & \multicolumn{2}{|c|}{ RLS } & FA & \multirow{2}{*}{$\frac{\mathrm{HQ}}{0.518^{* *}}$} & \multirow{2}{*}{$\begin{array}{l}\text { RLRV } \\
0.504^{* *}\end{array}$} & FUA \\
\hline STA & $0.540 * *$ & $0.495^{* *}$ & $0.536^{* *}$ & $0.610^{* * *}$ & \multicolumn{2}{|c|}{$0.174 * *$} & \multicolumn{2}{|c|}{$0.200^{* *}$} & $0.538^{* *}$ & & & $0.528 * *$ \\
\hline ANG & & $0.579 * *$ & $0.538 * *$ & $0.601^{*}$ & 0.28 & $* * *$ & 0.2 & $4 * *$ & $0.452 * *$ & $0.477 * *$ & $0.392 * *$ & $0.482 * *$ \\
\hline BD & & & $0.590 * *$ & $0.540^{\prime}$ & 0.29 & *** & 0.2 & $5 * *$ & $0.480^{* *}$ & $0.478 * *$ & $0.470 * *$ & $0.492 * *$ \\
\hline $\mathrm{CW}$ & & & & $0.746^{\prime}$ & 0.29 & ;** & 0.3 & $1 * *$ & $0.616^{* *}$ & $0.642 * *$ & $0.610^{* *}$ & $0.506^{* *}$ \\
\hline RW & & & & & 0.34 & ** & 0.3 & $7 * *$ & $0.653^{* * *}$ & $0.659 * *$ & $0.565^{* *}$ & $0.536^{* *}$ \\
\hline RA & & & & & & & & $7 * *$ & $0.347 * *$ & $0.239 * *$ & $0.165^{* *}$ & $0.093^{*}$ \\
\hline RLS & & & & & & & & & $0.334 * *$ & $0.364 * *$ & $0.500^{* *}$ & $0.271^{* *}$ \\
\hline FA & & & & & & & & & & $0.638 * *$ & $0.554 * *$ & $0.565^{* *} *$ \\
\hline HQ & & & & & & & & & & & $0.626 * *$ & $0.459 * *$ \\
\hline RLRV & & & & & & & & & & & & $0.510^{* *}$ \\
\hline & RUH & $\mathrm{CL}$ & UD & FIP & $\mathrm{TL}$ & & & DF & $\mathrm{BC}$ & $\mathrm{F} \& \mathrm{~L}$ & $\mathrm{UC}$ & FS \\
\hline STA & $0.467 * *$ & $0.519 * *$ & $0.001^{\text {ös }}$ & $0.363^{* *} *$ & $0.259 * *$ & 0.13 & $3 * *$ & $0.453^{* *}$ & $0.458 * *$ & $0.401 * *$ & $0.451 * *$ & $0.475^{* * *}$ \\
\hline ANG & $0.487 * *$ & $0.570^{* *}$ & $0.182 * *$ & $0.311^{* *}$ & $0.293^{* * *}$ & 0.27 & *** & $0.585^{* * *}$ & $0.440^{* *}$ & $0.467 * *$ & $0.518 * *$ & $0.550 * *$ \\
\hline BD & $0.457 * *$ & $0.458 * *$ & $0.121 * *$ & $0.343^{* *} *$ & $0.239 * *$ & 0.21 & $* *$ & $0.397 * *$ & $0.426 * *$ & $0.405 * *$ & $0.425 * *$ & $0.457^{* * *}$ \\
\hline $\mathrm{CW}$ & $0.489^{* *}$ & $0.479 * *$ & -0.013 ös & $0.454 * *$ & $0.281^{* *} *$ & 0.15 & $3 * *$ & $0.410 * *$ & $0.424 * *$ & $0.375^{* *}$ & $0.401 * *$ & $0.440^{* * *}$ \\
\hline RW & $0.529 * *$ & $0.536^{* *}$ & $0.097^{*}$ & $0.494 * *$ & $0.358^{* *} *$ & 0.22 & $5 * *$ & $0.488^{* * *}$ & $0.463^{* *}$ & $0.440 * *$ & $0.453^{* *}$ & $0.507 * *$ \\
\hline RA & $0.132 * *$ & $0.180^{* *}$ & $0.201 * *$ & $0.237 * *$ & $0.365^{* *} *$ & 0.3 & $3 * *$ & 0.064 ös & $0.079 *$ & $0.037^{\text {ös }}$ & $0.037^{\text {ös }}$ & 0.069 ös \\
\hline RLS & $0.151^{* *}$ & $0.179 * *$ & $0.015^{\text {ös }}$ & $0.275^{* *}$ & $0.314^{* *}$ & 0.1 & $4 * *$ & $0.089 *$ & 0.007 ös & $0.047^{\text {ös }}$ & $0.032^{\text {ös }}$ & 0.032 ös \\
\hline FA & $0.468 * *$ & $0.524 * *$ & $0.085^{\text {ös }}$ & $0.463^{* *}$ & $0.328 * *$ & 0.1 & $7 * *$ & $0.365 * *$ & $0.338 * *$ & $0.338 * *$ & $0.348 * *$ & $0.385^{* *} *$ \\
\hline HQ & $0.502 * *$ & $0.535^{* *} *$ & $0.057^{\text {ös }}$ & $0.416^{* *}$ & $0.234 * *$ & 0.1 & & $0.359 * *$ & $0.321 * *$ & $0.342 * *$ & $0.331 * *$ & $0.371 * *$ \\
\hline RLRV & $0.392 * *$ & $0.428 * *$ & $-0.071^{\text {ös }}$ & $0.408^{* *}$ & $0.202^{* *}$ & 0.0 & & $0.218^{* *} *$ & $0.178^{* *}$ & $0.204^{* *}$ & $0.197 * *$ & $0.213^{* *} *$ \\
\hline FUA & $0.593^{* *}$ & $0.531 * *$ & $0.137 * *$ & $0.473^{* *}$ & $0.250^{* *}$ & 0.2 & $3 * *$ & $0.474 * *$ & $0.467 * *$ & $0.471^{* *}$ & $0.517 * *$ & $0.533 * *$ \\
\hline RUH & & $0.733^{* *}$ & $0.144 * *$ & $0.404 * *$ & $0.110^{*}$ & 0.1 & *** & $0.483 * *$ & $0.473 * *$ & $0.487 * *$ & $0.472 * *$ & $0.508 * *$ \\
\hline CL & & & $0.186^{* *}$ & $0.424 * *$ & $0.205^{* *} *$ & 0.2 & $7 * *$ & $0.572 * *$ & $0.462 * *$ & $0.493^{* *}$ & $0.529 * *$ & $0.546^{* * *}$ \\
\hline UD & & & & $0.316^{* *}$ & $0.291 * *$ & 0.4 & $* *$ & $0.173^{* *} *$ & $0.133^{* *}$ & $0.178 * *$ & $0.158 * *$ & $0.181^{* *} *$ \\
\hline FTP & & & & & $0.450^{* *}$ & 0.4 & $* *$ & $0.355^{* * *}$ & $0.294^{* *} *$ & $0.291 * *$ & $0.349 * *$ & $0.357 * *$ \\
\hline TL & & & & & & 0.5 & *** & $0.258 * *$ & $0.184 * *$ & $0.210^{* *}$ & $0.224 * *$ & $0.234 * *$ \\
\hline RTP & & & & & & & & $0.259 * *$ & $0.233^{* *} *$ & $0.204 * *$ & $0.232 * *$ & $0.246^{* * *}$ \\
\hline DF & & & & & & & & & $0.724 * *$ & $0.740 * *$ & $0.795 * *$ & $0.858 * *$ \\
\hline $\mathrm{BC}$ & & & & & & & & & & $0.744^{* *} *$ & $0.713^{* *}$ & $0.846^{* * *}$ \\
\hline $\mathrm{F} \& \mathrm{~L}$ & & & & & & & & & & & $0.752 * *$ & $0.868^{* * *}$ \\
\hline $\mathrm{UC}$ & & & & & & & & & & & & $0.925^{* *} *$ \\
\hline
\end{tabular}

Rump Width, RA: Rump Angle, RLS: Rear Legs Set, FA: Foot Angle, HQ: Hocks, RLRV: Rear Legs Rear View, FUA: Fore Udder Attachment, RUH: Rear Udder Height, CL: Central Ligament, UD: Udder Depth, FTP: Front Teat Placement, TL: Teat Length, RTP: Rear Teat Placement, DF: Dairy Form, BC: Body Capacity, F\&L: Feet and Legs, UC: Udder Composite, FS: Final Score.

Although milk yield records were obtained from 533 cows scored in the study, the lactation period could only be determined in the records of 325 cows. The averages for 305-day milk yields (305dMY) were obtained from the lactation of 533 cows and were found to be $5692.92 \pm 62.43 \mathrm{~kg}$. Milk yield varied between 1820 and $9096 \mathrm{~kg}$. The standard deviation and variation coefficient was estimated to be 1441.21 and 25.32 (\%), respectively.
Genetic correlations between 305-dMY and type traits ranged from -0.93 (RW) to 0.70 (BC and FS) (Table 4). This value was estimated as -0.49 , $0.14,0.35,0.40,0.11,-0.65,0.31$ and 0.54 for STA, ANG, HQ, RUH, CL, TL, F\&L, and UC. 
Table 4. Phenotypic (rP) and genetic (rG) correlations and their standard errors $( \pm \mathrm{SE})$ between type traits and 305-dMY

\begin{tabular}{lcc} 
Traits & $\mathrm{rP} \pm \mathrm{SE}$ & $\mathrm{rG} \pm \mathrm{SE}$ \\
\hline STA & $0.28 \pm 0.04$ & $-0.49 \pm 1.24$ \\
ANG & $0.28 \pm 0.04$ & $-0.14 \pm 1.04$ \\
BD & $*$ & $*$ \\
CW & $*$ & $*$ \\
RW & $0.30 \pm 0.04$ & $-0.93 \pm 1.39$ \\
RA & $*$ & $*$ \\
RLRV & $*$ & $*$ \\
FA & $*$ & $*$ \\
HQ & $0.21 \pm 0.04$ & $0.35 \pm 1.75$ \\
RLRV & $*$ & $*$ \\
FUA & $*$ & $*$ \\
RUH & $0.35 \pm 0.04$ & $0.40 \pm 0.67$ \\
CL & $0.39 \pm 0.04$ & $0.11 \pm 0.80$ \\
UD & $*$ & $*$ \\
FTP & $*$ & $*$ \\
TL & $-0.06 \pm 0.05$ & $-0.65 \pm 0.58$ \\
RTP & $*$ & $*$ \\
DF & $*$ & $0.70 \pm 0.57$ \\
BC & $0.46 \pm 0.04$ & $0.31 \pm 0.67$ \\
F\&L & $0.48 \pm 0.04$ & $0.54 \pm 0.57$ \\
UC & $0.56 \pm 0.03$ & $0.70 \pm 0.46$ \\
FS & $0.58 \pm 0.03$ &
\end{tabular}

*: It couldn't be calculated, SE: Standart Error STA: Stature, ANG: Angularity, BD: Body Depth, CW: Chest Width, RW: Rump Width, RA: Rump Angle, RLS: Rear Legs Set, FA: Foot Angle, HQ: Hocks, RLRV: Rear Legs Rear View, FUA: Fore Udder Attachment, RUH: Rear Udder Height, CL: Central Ligament, UD: Udder Depth, FTP: Front Teat Placement, TL: Teat Length, RTP: Rear Teat Placement, DF: Dairy Form, BC: Body Capacity, F\&L: Feet and Legs, UC: Udder Composite, FS: Final Score.

Phenotypic correlations between milk yield and type traits were estimated between -0.06 (TL) and 0.58 (FS). It was estimated as $0.28,0.28,0.30$, $0.21,0.35,0.39,0.46,0.48$, and 0.56 for STA, ANG, RW, HQ, RUH, CL, BC, F\&L and UC respectively. Phenotypic correlations for $\mathrm{BD}$, CW, RA, RLS, FA, RLRV, FUA, UD, FTP, RTP, and DF could not be calculated in ASREML program.

Meyer et al. (1987) reported that phenotypic correlations between type traits and milk yield are low and below 0.30. It has been reported by Klassen et al. (1992) that phenotypic correlations between lifetime yield and type traits are mostly low positive. The researchers estimated the highest phenotypic correlation between milk yield and DF as 0.22. Yaylak (2008) reported that the phenotypic correlation between milk yield and UD was -0.20 , while this value was found to be zero for RTP and FA. In his study Duru (2005) have found the phenotypic correlations between milk yield and STA, ANG, BD, CW RW, RA. RLS, FA, HQ, RLRV, FUA, RUH, CL ,UD, FTP, RTP, DF, BC, F\&L and UC as 0.05, 0.02, 0.21, $0.00,0.08,-0.10,0.04,0.08,0.31,0.12,0.00,0.22$, $0.03,-0.19,-0.02,-0.08,0.24,0.08,0.16,0.00$, and 0.04 respectively and the fact that $\mathrm{CW}$ and FUA is zero and FTP is very low is similar to this study.

Placke et al. (1983) report the genetic correlation between 100-day milk yield and final score (FS) as 0.32 while stating that the genetic correlations between type traits and 305-dMY are significant. Meyer et al. (1987) report that the genetic correlations between type traits and milk yield are low, but some of them are statistically significant. They estimated the genetic correlations between milk yield in the first lactation and UD, FUA, and RW as $-0.52,-0.37$, and -0.35 , respectively, and those between UD, ANG, and FUA in the second lactation as $-0.46,0.42$, and -0.30 , respectively. As a result, researchers reported that type traits may not be useful in estimating yield. Klassen $e t$ al. (1992) report that the DF property has the highest genetic correlation with milk yield, and this value is estimated at 0.53. Researchers estimated correlations between milk yield and ANG, UD, and FUA as 0.59, -0.44, and -0.31 , respectively, while they reported that some type traits were negatively affected when performing selection to increase milk yield. Of these, udder traits are reported to be the most affected, while there is also reported to be a decrease in milk yield progress of about $15 \%$ when performing selection concerning the udder base. Genetic correlations between milk yield and ANG, UD, and FUA were estimated by Short and Lawlor (1992) as 0.52, 0.41 , and -0.23 , respectively. Visscher and Goddard (1995) report that the genetic correlation between milk yield and DF in Holstein is 0.50, while the correlations between milk yield and DF, ANG, UD, RUH, FTP, and CL in Jersey cows are $0.84,0.76,0.60,0.51,0.40$ and 0.37 , respectively. Degroot et al. (2002) estimated the genetic correlations between milk yield and ANG, RLS, UD, RA, and FUA as 0.91, 0.83, -0.65, 0.62, and -0.45 , respectively. Tapk1 and Guzey (2013) found phenotypic correlations between type traits and milk yield as -0.31 and 0.29 in their study of Holstein cattle. 
It was found that the dairy trait was associated positively with height, strength, body depth, rump width, side view of the rear foot, central ligament, rear udder height, rear udder width, and rear view of the foot and negatively with rump slope and udder depth (Yaylak, 2008). Erkmen (2020) detected high genetic correlations with 305-dMY as positive with ANG (0.96), BD (0.81), and RUH (0.65) and negative with RLRV (-0.90), and emphasized that cows with a deeper body, a higher rear udder, and a steeper foot structure will have higher milk yield in a delicate dairy trait. He again found positive correlations between 305dMY and STA, CW, RA, RW, and F\&L, ranging from 0.40 to 0.48 .

While some of the genetic correlations obtained in the study were similar to the values reported by Meyer et al. (1987), Short and Lawlor (1992), Klassen et al. (1992), Visscher and Goddard (1995), and Degroot et al. (2002) among the studies given above, some correlations were found to be quite high, while others were not detected. In his study Duru (2005) determined the genetic correlations between 305-dMY and STA, ANG, BD, CW, RW, RA, RLS, FA, HQ, RLRV, FUA, RUH, CL, UD, DT, FTP, RTP, DF, BC, F\&L and UC as 0.14, 0.21, 0.13, 0.24, 0.19, -0.04, $0.250 .58,-0.09,0.05,0.15,0.64,0.000,-0.13$, $0.01,-0.02,0.04,0.39,0.07,1.00$, and 1.00 respectively. In particular, the relationship between F\&L and UC with milk yield is noteworthy, and selection to improve these traits can also increase milk yield.

In this study, it was determined that there was a high level of genetic correlation between 305 dMY and non-linear traits of BC, F\&L, UC, and FS. Additionally, a high level of genetic correlation was found between 305-dMY and BC, F\&L, UC, and FS, which are nonlinear traits. The phenotypic correlations between these traits themselves are high. Given that both the excess number of traits used in the linear definition and the correlations of these traits with each other and with milk yield are generally low, it is necessary to focus on FS and the traits used in the calculation of FS (DF, BC, F\&L, and UC). It is possible to use these traits as an indirect selection criterion in the selection to be made for milk yield.

\section{CONCLUSION}

In the study, heritability levels of type traits and linear identification traits were generally estimated at low and moderate levels. Of the phenotypic correlations between type traits, phenotypic correlations between final score and various type traits were found to be high and significant. Among the properties used in the classification according to the type traits, it was found that four non-linear traits $(\mathrm{DF}, \mathrm{BC}, \mathrm{F} \& \mathrm{~L}$, and UC) and the final score calculated from these traits are the traits that are more practical to apply, which can be best used by the breeder. Besides, the fact that these traits are in high correlations with other traits and milk yield can lead to the use of these traits as an indirect selection criterion in the selection to be made for milk yield.

\section{REFERENCES}

ALMEIDA, T.P.; KERN, E.L.; DALTRO, D.D.S. et al. Genetic associations between reproductive and lineartype traits of Holstein cows in Brazil. Rev. Bras. Zootec., v.46, p.91-98, 2017.

BOLDMAN, K.G.; FREEMAN, A.E.; HARRIS, B.L.; KUCK, A.L. Prediction of sire transmitting abilities for herd life from transmitting abilities for linear type traits. J. Dairy Sci. v.75, p.552-563, 1992.

CASSEL, B. Using heritability for genetic improvement. Ext. Dairy Sci. Genet. Manag. Univ. Dairy Sci., n.404-408, 2001.

ÇERÇI, S. Type traits of Holstein-Friesian cattle raised in some dairy farms in Aydin province. 2006. Thesis (Master) - Adnan Menderes Üniviversite Fen Bilimleri Enstitüsü, TUR.

DECHOW, C.D.; ROGERS, G.W.; KLEI, L.; LAWLOR, T. J. Heritabilities and correlations among body condition score, dairy form, and selected linear type traits. J. Dairy Sci., v.86, p.2236-2242, 2003.

DEGROOT, B.J.; KEOWN, J.F.; VAN VLECK, L.D.; MAROTZ, E.L. Genetic parameters and responses of linear type, yield traits and somatic cell scores to divergent selection for predicted transmitting ability for type in Holsteins. J. Dairy Sci., v.85, p.1578-1585, 2002.

DURU, S. Estimation of parameter and breeding value type traits in Holstein cattle. 2005. Thesis (Doctoral) Uludağ Üniversite. Fen Bilimleri Enstitüsü, Bursa, TUR.

ERKMEN, R. Relationship between linear type traits with milk yield and reproductive traits in Holstein cows. 2020. Thesis (Master) - Kurşehir Ahi Evran Üniversitesi, Fen Bilimleri Enstitüsü, Kırşehir, TUR. 
FATEHI, J.; STELLA, A.; SHANNON, J.J.; BOETTCHER, P.J. Genetic parameters for feet and leg traits evaluated in different environments. J. Dairy Sci., v.86, p.661-666, 2003.

GILMOUR, A.R.; GOGEL, B.J.; CULLIS, B.R.; WELHAM, S.J.; THOMPSON, R. Asreml user guide release 2.0. VSN International, HP1 1 ES, UK, 2007.

IRANO, N.; BIGNARDI, A.B.; EL FARO, L. et al. Genetic association between milk yield, stayability, and mastitis in Holstein cows under tropical conditions. Trop. Anim. Health Prod., p.46, v.529-535, 2014.

KADARMIDEEN, H.N.; WEGMANN, S. Genetic parameters for body condition score and it's relationship with type and production traits in Swiss Holsteins. J. Dairy Sci., v.86, p.3685-3693, 2003.

KERN, E.L.; COBUCI, J.A.; COSTA, C.N.; MCMANUS, C.M.; BRACCINI NETO, J. Genetic association between longevity and linear type traits of Holstein cows. Sci. Agric., v.72, p.203-209, 2015.

KLASSEN, D.J.; MONARDES, H.G.; JAIRATH, L.; CUE, R.I.; HAYES, J.F. Genetic correlations between lifetime production and linearized type in Canadian Holsteins. J. Dairy Sci., v.75, p.2272-2282, 1992.

KUL, E.; ERDEM, H. Relationships between somatic cell count and udder traits in Jersey cows. J. Appl. Anim. Res., v.34, p.101-104, 2008

KUMLU, S. Dairy and slaughter cattle breeding. Türk. Damızlık Siğır Yetiştiricileri Merkez Birliği Yay, v.3, p.31-44, 2000.

MEYER, K.; BROTHERSTONE, S.; HILL, W.G.; EDWARDS, M.R. Inheritance of linear type traits in dairy cattle and correlations with milk production. Anim. Prod., v.44, p.1-10, 1987.

MIKHCHI, A.; MASHHADI, M.H.; JAFARABADI, G.A. Estimation of genetic parameters for udder type traits in the first lactation of Iranian dairy Holstein cattle. Res. Opin. Anim. Vet. Sci., v.3, p.457-461, 2013.

ÖZCAN, K. Classification of cattle according to morphological features. Damızlık Siğır Yetisstiricileri Derg. v.12, p.15, 2001.

ÖZET, H. The relationship between linear type traits and milk yield of Holstein cows bred and ceylanpınar agricultural station. 2001. Thesis (Doctoral) - Firat Üniversit Fen Bilimleri Enstitüsü. Elazığ, TUR.

PLACKE, K.H.; ClAUS, J.; KALM, E. Type classification of German black pied cattle. 2. heritabilities and phenotypic and genetic correlations. Zuchtungskunde, v.55, p.258-264, 1983.

PRYCE, J.E.; COFFEY, M.P.; BROTHERSTONE, S. The genetic relationship between calving interval, body condition score, and linear type and management traits in registered Holsteins. J. Dairy Sci., v.83, p.2664$2671,2000$.
ROGERS, G.W. Index selection using milk yield, somatic cell score, udder depth, teat placement, and foot angle. J. Dairy Sci. v.76, p.664-670, 1993.

ROYAL, M.D.; PRYCE, J.E.; WOOLLIAMS, J.A.; FLINT, A.P.F. The genetic relationship between commencement of luteal activity and calving interval, body condition score, production, and linear type traits in Holstein-Friesian dairy cattle. J. Dairy Sci., v.85, p.3071-3080, 2002.

SHORT, T.H.; LAWLOR, T.J. Genetic parameters of conformation traits, milk yield, and herd life in Holsteins. J. Dairy Sci., v.75, p.1987-1998, 1992.

SMOTHERS, C D.; PEARSON, R.E.; HOESCHELE, L. Herd final score and its relationship to genetic and environmental parameters of conformation traits of United States Holsteins. J. Dairy Sci., v.76, p.16711677, 1993.

STATISTICS made visual. JMP 3.2. [s.1.]: [SAS Institute], 1995.

STEFANI, G.; EL FARO, L.; SANTANA JÚNIOR, M.L.; TONHATI, H. Association of longevity with type traits, milk yield, and udder health in Holstein cows. Livest. Sci., v.218, p.1-7, 2018.

TAPKI, I.; GUZEY, Y.Z. Genetic and phenotypic correlations between linear type traits and milk production yields of Turkish Holstein dairy cows. Greener J. Agricult. Sci., v.3, p.755-761, 2013.

THE HOLSTEIN Foundation's dairy judging workbook. [s.n.]: [s.1.], 1997. p.48-49.

TOOSI, A.; EFTEKHARI, F. Estimation of the effects of some environmental factors and genetic parameters of linear type traits in Holstein Cows of Iran. Dept. of Anim. Sci., College of Agriculture. Ferdowsi Univ. Mashhad. Iran. 2000.

VALloto, A.A. Características lineares de tipo e produção em vacas primíparas, parâmetros genéticos. 2016. 106f. Dissertação (Mestrado em Zootecnia). Universidade Federal do Paraná, PR.

VISSCHER, P.M.; GODDARD, M.E. Genetic parameters for milk yield, survival, workability, and type traits for Australian dairy cattle. J. Dairy Sci., v.78, p.205-220, 1995.

WASANA, N.; CHO, G.; PARK, S.; KIM, S.; CHOI, J.; PARK, B.; DO, C. Genetic relationship of productive life, production, and type traits of Korean Holsteins at early lactations. Asian-Australas. J. Anim. Sci., v.28, p.1259-1265, 2015.

YAYLAK, E. Phenotypic correlations between type traits and milk yield criterions in Holstein cow. Selcuk J. Agricult. Food Sci., v.22, p.19-25, 2008. 